\title{
The effects of Zhikang capsule on the growth and apoptosis of breast cancer MCF-7.
}

\author{
Cheng Chong ${ }^{1,2}$, Lv Yi ${ }^{1 *}$, Han Wei ${ }^{2}$, Liang Daoyan ${ }^{2}$, Zhu Xulong², Ma Gang², Zhang En², Li Jianhui \\ ${ }^{1}$ Department of Hepatobiliary Surgery, the First Affiliated Hospital of Xi'an JiaoTong University, Xi'an, PR China \\ ${ }^{2}$ Oncological Surgery of Shaanxi People's Hospital, Xi'an, PR China
}

\begin{abstract}
Objective: To investigate the effect of the Zhikang capsule on the growth and apoptosis of breast cancer cell line MCF-7.

Method: MTT method was used to detect the growth situation of normal breast cancer MCF-7 cells at $24 \mathrm{~h}, 48 \mathrm{~h}$ and $72 \mathrm{~h}$ after treatment by Zhikang capsule and the effects of Zhikang capsule on cell cycle of MCF-7 cells were detected by flow cytometry using flow cytometer. The effects of $24 \mathrm{~h}, 48 \mathrm{~h}$ and $72 \mathrm{~h}$ after treatment by Zhikang capsule on the growth of normal breast cancer MCF-7 cells were measured by flow cytometry; the effect of Zhikang capsule on apoptosis of MCF-7 cells was detected by PI single staining flow cytometry.

Result: Different concentrations of Zhikang capsule could effectively inhibit the growth of MCF-7 cells, and with the increase of concentration and extension of action time, the cell growth inhibition rate increased. The MCF-7 cells were effect for $72 \mathrm{~h}$ by the $0.5,1,2.0 \mathrm{mg} / \mathrm{ml}$ of the Zhikang capsule, and the proportion of G0/G1 phase cells in cell cycle was $19.33 \pm 10.38 \%, 14.12 \pm 5.37 \%$ and $26.84 \pm 2.13 \%$; While the control group G0/G1 phase ratio was $51.83 \pm 1.90 \%$. The apoptosis rate of the cells were 2.09 $\pm 0.74 \%, 3.84 \pm 0.78 \%$ and $5.35 \pm 0.83 \%$ respectively treated by the $0.5,1,2.0 \mathrm{mg} / \mathrm{ml}$ of the Zhikang capsule.

Conclusion: The Zhikang capsule could inhibit the growth of MCF-7 cells in vitro, and the inhibitory effect showed the time effect and dose effect relationship; and it could promote the apoptosis of breast cancer cells by blocking the cell cycle in the G2/M phase.
\end{abstract}

Keywords: Breast cancer, Zhikang capsule, Cell growth, Cell cycle.

Accepted on March 07, 2018

\section{Introduction}

The Zhikang capsule was composed by 14 kinds of traditional Chinese medicines including Rhubarb, Coptis chinensis, pseudo-ginseng, radix angelicae, donkey-hide gelatin, fossil fragments, common Bletilla tuber, stir-baked Myrrha with vinegar, cuttle-bone, madder, resina draconis, liquorice, pearl, borneol. It had the function of heat clearing and hemostasis, Qufushengji, relieving pain, promoting tissue repair and shorten the time of wound healing. It was more common to find the skin flap necrosis, infection and subcutaneous effusion after modified radical mastectomy for breast cancer. Once the wound healing time was prolonged, it would bring unnecessary pain to patients, prolong the length of stay, increase the economic burden and delay the implementation of other treatment options. Over the years, surgeons have been actively looking for effective ways to promote wound healing. Through the literature we knew that Zhikang capsule can promote the healing of the wound, but it was rarely used in skin flap in patients with breast cancer healing reports. In this study, in vitro culture of breast cancer cell line MCF-7 cells were as the research object, then we observed the effect of the Zhikang capsule on the growth of MCF-7 cells, and it provided a new treatment for breast cancer patients with wound healing.

\section{Materials and Methods}

\section{Cell lines, experimental drugs and reagents}

MCF-7 human breast cancer cell line was presented by Cancer Research Institute of the First Affiliated Hospital of Xi'an Jiao Tong University. Zhikang capsule was purchased from Xi'an Millennium Pharmaceutical Co., Ltd. Fetal bovine serum was purchased from Sijiqing Zhejiang Tianhang Biological Technology Co., Ltd.

H-DMEM was purchased from Hyclone Company. MTT and DMSO were purchased from Sigma Company. Annexin-VFITC/PI apoptosis detection kit was purchased from beyotime Biotechnology Research Institute. 


\section{Detection the effect of Zhikang capsule on the growth of MCF-7 cells by MTT method}

MCF-7 cells were cultured in H-DMEM culture medium containing $10 \%$ fetal bovine serum under the condition of $5 \%$ $\mathrm{CO}_{2}$ and $37^{\circ} \mathrm{C}$. Liquid was changed 1 time every $24 \mathrm{~h}$. MCF-7 cells were digested with $0.25 \%$ trypsin solution during the logarithmic growth phase. The experimental group were respectively added $0.5,1,2.0 \mathrm{mg} / \mathrm{ml}$ of the Zhikang capsules $200 \mu \mathrm{l}$, the control group were added the same amount of culture fluid, then each hole was added MTT $(5 \mathrm{mg} / \mathrm{ml}) 20 \mu \mathrm{l}$ after the culture of $24 \mathrm{~h}, 48 \mathrm{~h}, 72 \mathrm{~h}$. Each hole was added with $150 \mu \mathrm{l}$ DMSO, and oscillated for $10 \mathrm{~min}$, and the value was measured by the enzyme standard instrument in the $490 \mathrm{~nm}$ absorbance (A). The experiment was carried out 2 times, and taken the average (A) value of the 2 results. Cell growth inhibition rate $=($ control group $\mathrm{A}$ value-treatment group $\mathrm{A}$ value)/control group A value $\times 100 \%$.

\section{Detection the effect of Zhikang capsule on cell cycle of MCF-7 cells by flow cytometry}

MCF-7 cells were inoculated in the culture bottle, and divided into control group and $0.5,1,2.0 \mathrm{mg} / \mathrm{ml}$ of the capsule groups. The control group was added with an equal amount of $10 \%$ fetal calf serum containing high glucose DMEM complete medium. Cell cycle distribution was analyzed by computer software and flow cytometry.

\section{Detection the effect of on the apoptosis of MCF-7 cells induced by Kang capsule by Annexin-V-FITC/PI double labelled fluorescent staining}

MCF-7 cells were inoculated in the culture bottle, and divided into control group and $0.5,1,2.0 \mathrm{mg} / \mathrm{ml}$ of the capsule groups. Each tube was added $195 \mu$ l Annexin-V-FITC binding buffer solution and $5 \mu \mathrm{l}$ PI solution. It was detected by Flow cytometry, and the data was processed and printed by computer. The experiment was repeated 3 times.

\section{Statistical methods}

The data was processed by SPSS13.0 statistical software, and the measurement data was showed by $\overline{\mathrm{x}} \pm \mathrm{s}$. One way ANOVA was used to analyze the difference between the two groups, and the difference was statistically significant with $\mathrm{P}<0.05$.

\section{Results}

\section{Inhibitory effect of Zhikang capsule on the growth of MCF-7 cells}

Different concentrations of the Zhikang capsule could effectively inhibit the growth of MCF-7 cells. At the same time of action ( $24 \mathrm{~h}, 48 \mathrm{~h}, 72 \mathrm{~h}$ ), with the increase of the concentration of the drug, the inhibition effect on the growth of MCF-7 cells was gradually increased $(\mathrm{P}<0.05)$ (Table 1$)$. It was no obvious inhibitory effect on cells when the concentration of Zhikang capsule was less than $0.5 \mathrm{mg} / \mathrm{ml}$.
There was a small amount of living cell growth after $24 \mathrm{~h}$ of training when the concentration of Zhikang capsule was more than $4.0 \mathrm{mg} / \mathrm{ml}$ (Figure 1).

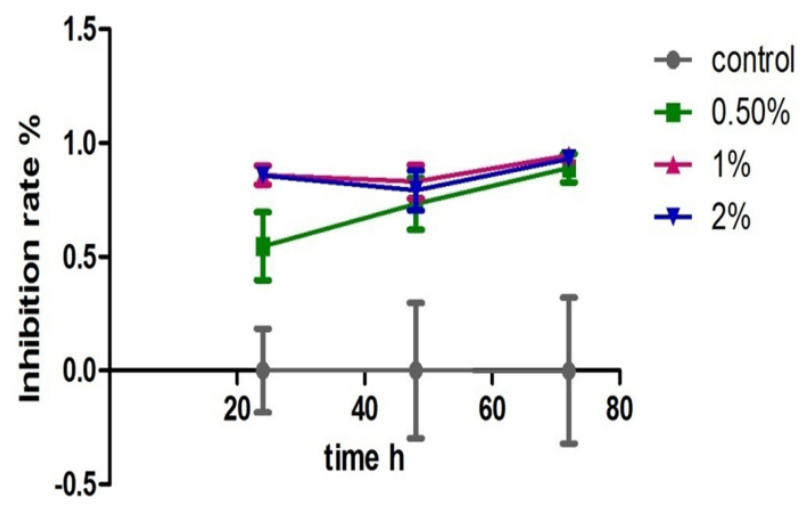

Figure 1. The effect of different concentrations of the Zhikang capsule on the growth inhibition rate of MCF-7 cells.

\section{Detection the effect of Zhikang capsule on cell cycle of MCF-7 cells by flow cytometry}

Detection results of cell cycle showed that the cell cycle distribution of cells was changed and the cycle of MCF-7 cells was significantly blocked after treated by the concentration of $0.5,1,2.0 \mathrm{mg} / \mathrm{ml}$ of the Zhikang capsule. The $\mathrm{S}$ phase of 2.0 $\mathrm{mg} / \mathrm{ml}$ high concentration group of Zhikang capsule increased from $44.85 \pm 2 \%$ to $57.53 \pm 6.57 \%(\mathrm{P}<0.05)$ and the $\mathrm{G} 2 / \mathrm{M}$ phase increased from $3.32 \pm 2.51 \%$ to $16.66 \pm 8.51 \%(\mathrm{P}<0.05)$. The difference was statistically significant. The proportion of cell cycle in G0/G1 phase was $19.33 \pm 10.38 \%, 14.12 \pm 5.37 \%$ and $26.84 \pm 2.13 \%$. The proportion of $\mathrm{G} 0 / \mathrm{G} 1$ phase in the control group was $51.83 \pm 1.90 \%$. There were significant differences in the proportion of cell cycle of $\mathrm{G} 0 / \mathrm{G} 1$ phase cells in different concentrations of the Zhikang capsule group compared with the control group $(\mathrm{P}<0.05)$ (Figures $2 \mathrm{~A}-2 \mathrm{D})$.

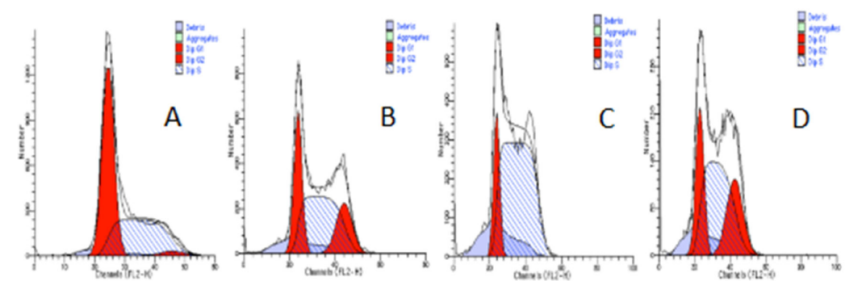

Figure 2. Detection the effect of Zhikang capsule on cell cycle of MCF-7 cells by FCM. (A) Treated with 0.1\% DMSO; (B-D) Treated with Zhikang capsule (the concentration was $0.5,1,2.0 \mathrm{mg} / \mathrm{ml}$ ).

\section{Detection of apoptosis of breast cancer cells by Annexin-V-FITC/PI double staining flow cytometry}

After treatment $48 \mathrm{~h}$ by Zhikang capsule, the apoptosis rate of the cells was significantly increased.

The apoptosis rate was $2.09 \pm 3.84 \%, 0.74 \pm 0.78 \%$ and $5.35 \pm$ $0.83 \%$ after treatment of $0.5,1,2.0 \mathrm{mg} / \mathrm{ml}$ Zhikang capsule for $48 \mathrm{~h}$.

Table 1. The effect of different concentrations of the Zhikang capsule on the proliferation inhibition rate of MCF-7 cells. 


\begin{tabular}{llll}
\hline \multirow{2}{*}{ Drug concentration } & \multicolumn{3}{l}{ Cell proliferation inhibition rate (\%) } \\
\cline { 2 - 4 } & $\mathbf{2 4} \mathrm{h}$ & $\mathbf{4 8 ~ h}$ & $\mathbf{7 2 ~ h}$ \\
\hline Blank control group & $0.000 \pm 0.184$ & $0.000 \pm 0.297$ & $0.000 \pm 0.320$ \\
\hline Zhikang capsule $(\mathrm{mg} / \mathrm{ml})$ & & \\
\hline $0.5 \mathrm{mg} / \mathrm{ml}$ & $0.547 \pm 0.150^{*}$ & $0.733 \pm 0.114^{*}$ & $0.890 \pm 0.628^{*}$ \\
\hline $1.0 \mathrm{mg} / \mathrm{ml}$ & $0.859 \pm 0.417^{*}$ & $0.830 \pm 0.744^{*}$ & $0.945 \pm 0.306^{*}$ \\
\hline $2.0 \mathrm{mg} / \mathrm{ml}$ & $0.858 \pm 0.192^{*}$ & $0.792 \pm 0.875^{*}$ & $0.930 \pm 0.366^{*}$ \\
\hline $4.0 \mathrm{mg} / \mathrm{ml}$ & - & - & - \\
\hline${ }^{*}$ Compared with the control group P<0.05. & & \\
\hline
\end{tabular}

\section{Discussion}

The anti-tumor mechanism of traditional Chinese medicine has many aspects. Such as, inhibition of DNA synthesis, inhibition of tumor angiogenesis, inducing cell differentiation, promoting cell apoptosis, regulating the body's immune function, inhibiting protein tyrosine kinase (tyrosine kinase protein, PTK) activity, etc. [1-4]. The Zhikang capsule was composed by Rhubarb, Coptis chinensis, pseudo-ginseng, common Bletilla tuber and had the function of heat clearing and hemostasis, Qufushengji, relieving pain, promoting tissue repair and shorten the time of wound healing. It was confirmed by several experiments that Bletilla had antitumor activity. Aijing screened compounds extracted from Bletilla striata [5]. She found that the compound 1 was consistent with oleanolic acid-3-O- $\alpha$-L-rhamnose- $(1 \rightarrow 2)-\beta$-D- glucopyranoside and had some anti-tumor activity. It made the theoretical basis of Bletilla anticancer activity to be more confident. After the cell cycle was detected by flow cytometry, it was found that compound 1 could block the cell cycle in the G0/G1 phase and the synthesis of DNA. At the same time, there was a significant sub-G0/G1 peak in after compound 1 acting on lung adenocarcinoma cell A549 cells for $24 \mathrm{~h}$, which showed that the compound had the function of promoting the apoptosis of A549 cells. Bletilla also had the function of inducing apoptosis of tumor cells. Xuefen used $95 \%$ ethanol reflux to extract of Bletilla [6]. System solvent extraction method divided ethanol extract from Bletilla striata into petroleum ether layer, chloroform layer, ethyl acetate layer, butyl alcohol layer and water layer. CCK8 method was used to screen the active site of growth inhibition, and the effect of the active site on the apoptosis of mouse melanoma B16 cells was studied by fluorescence microscopy and flow cytometry analysis. The results showed that Bletilla chloroform and ethyl acetate layer inhibited on the growth of mouse melanoma B16 cells. The results showed that Bletilla chloroform layer could effectively induce B16 cell apoptosis. The results of this study showed that: the Zhikang capsule had a significant inhibitory effect on the growth of MCF-7 cells in the breast. With the increase of the concentration of the drug action and the extension of the action time, the inhibitory effect was time and concentration dependent.
The effect of promoting wound healing and hemostasis by Zhikang capsule has been widely affirmed [7,8]. Pharmacological studies showed that the main component of Zhikang capsule was rheum officinale, pseudo-ginseng and Bletilla. The pseudo-ginseng contained Panax Notoginseng Saponins, flavonoid glycoside and alkaloid, and had the function of hemostasis, analgesia and repair of mucous membranes. Bletilla contained the Bletilla hyacinthina gum. Bletilla striata polysaccharide could promote the growth of granulation tissue, capillary regeneration, and increase the wound exudate polymorphonuclear white cells and fibroblasts, and it was conducive to the wound to stop bleeding, repair and anti-infection [9-12]. Further study showed that Bletilla striata polysaccharide could increase the mRNA expression of macrophage inducible nitric oxide synthase, TNF- $\alpha$ and IL- $1 \beta$ and enhance the expression of these cytokines. The recent study found that the effective ingredients of Bletilla striata not only had the function of mechanical obstruction in the blood vessel, but also played a role in promoting blood coagulation and preventing the revascularization of the tumor [13]. It was confirmed that Bletilla had inhibitory effect on tumor growth of tumor bearing rabbit and Bletilla could inhibit tumor growth and narrow the tumor.

In conclusion, at the same time Zhikang capsule could promote the wound healing; it also might inhibit the tumor growth by blocking the cell cycle, inducing apoptosis, enhancing the expression of TNF- $\alpha$ and inhibiting tumor angiogenesis. It provided strong evidence for the application of Kang capsule in the wound healing after breast cancer surgery, but the specific molecular mechanism needed further study.

\section{Acknowledgement}

Shaanxi Province Key R\&D Planning Project, Project No.: 2017SF-051.

\section{References}

1. Dhno S, Tachibana M, Shibakita M. Prognostic significance of Fas and Fas ligand system-associated apoptosis in gastric cancer. Ann Surg Oncol 2000; 7: 750-757.

2. Nio Y, Iguchi C, Yamasawa K. Apoptosis and expression of $\mathrm{Bcl}-2$ and Bax proteins in invasive ductal carcinoma of the pancreas. Pancreas 2001; 22: 230-239.

3. Ma JX, Wang QZ, Su JY, Li HQ. Cells apoptosis in nude mice transplanted tumor of human esophageal cancer cellline induced by soybean isofiavone. Bulletin of Chinese Cancer 2004; 13: 34-37.

4. Huang H, Liu ZC. Antitumor effect of Shikonin and its derivatives. Chin J Cancer Prevention Treatment. 2005; 12: 75-78.

5. Sun AJ, Pang SQ, Wang GQ. Chemical constituents from Bletilla striata and their anti-tumor activities. Chin Pharm J 2016; 51: 101-104. 
6. Lu XF. Study of Rhizoma Bletillae striatae extracts in inducing apoptosis on mice melanoma B16 cells. Chin Archiv Trad Med 2013; 31: 1619-1621.

7. Shen X, Zhao ZP, Li DF. Study on the effects of Zhikang capsule to rat stress gastric ulcer. Chin J Basic Med Trad Med 2014; 20: 183-189.

8. Cheng C, Lv Y, Zhang E, Yan T. Effects of the Zhikang capsule on healing of the flap after radical breast cancer surgery. Genet Mol Res 2015; 14: 5127-5131.

9. Chou SL, Wang X, Li B. Histological study on effect of exogenous epidermal growth factor mixed with bletilia striata gelatin on promoting wound healing. Chin J Aesth Med 2006; 15: 1006-1009.

10. Liao JZ, Wang W, Luo YX. High-molecular-weight nerve growth factor with bletilla colloid as a carrier in the facilitation of wound healing. Chin J Clin Rehab 2006; 10: 179-181.

11. Wang C, Sun J, Luo Y. A polysaccharide isolated from the medicinal herb Bletilla striata induces endothelial cells proliferation and vascular endothelial growth factor expression in vitro. Biotechnol Lett 2006; 28: 539-543.
12. Diao H, Li X, Chen J. Bletilla striata Polysaccharide stimulates inducible nitric oxide synthase and proinflammatory cytokine expression in macrophages. J Biosci Bioeng 2008; 105: 85-89.

13. Liu SJ, Tong Y, Zhang M. Comparison study on the effects of Bletilla perfusion embolism to the rabbit VX2 liver cancer model CT image. Inform Trad Chin Med 2015; 32: 29-31.

\section{*Correspondence to}

Lv Yi

Department of Hepatobiliary Surgery

The First Affiliated Hospital of Xi'an JiaoTong University Xi'an

PR China 